\title{
The Effect Credit Restructuring Relaxation on Financial Performance in LPD Buleleng Regency During the Pandemic of Covid-19
}

\author{
Putu Eka Nopiyani1*, Ni Made Wulan Sari Sanjaya ${ }^{2 *}$, Riana Dewi Kartika ${ }^{3}$
}

${ }^{1}$ Sekolah Tinggi IlmuEkonomi Satya Dharma, Singaraja, Indonesia

\section{ART ICLE I N F O}

\section{Article history:}

Received August 04, 2021

Revised August 07, 2021

Accepted October 11, 2021

Available online November 25, 2021

Keywords:

Relaxation of Credit restructuring, Financial Performance, LPD

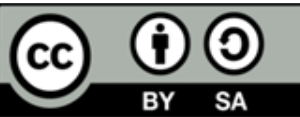

This is an open access article under the CC BY-SA license.

Copyright (C) 2021 by Author. Published by Universitas Pendidikan Ganesha.

\begin{abstract}
A B S T R A C T
During the Covid-19 pandemic, several Village Credit Institutions (LPD) experienced difficulties in their operations, so doing business would need to make various efforts. The implementation of various programs to support policies related to credit is carried out to maintain the growth of Village Credit Institutions (LPD), one of which is the relaxation of credit restructuring policies for people who have credit at Village Credit Institutions (LPD). This study aims to analyze the effect of the relaxation of credit restructuring on LPD financial performance during the Covid-19 pandemic. The nature of this research is an explanation with quantitative methods to test the causality of these variables. The variables in question are the relaxation of credit restructuring and performance. The total population of this study was 81 LPD. Determination of the sample using random sampling technique to obtain a total sample of $46 \mathrm{LPD}$. This research data collection uses documentation and questionnaire techniques. The data technique used in this study is a simple linear regression with the help of the SPSS 21 application. The results of this study are a positive analysis credit restructuring regression coefficient of 0.968 which means that each increase in credit restructuring by one unit will lead to an increase in the financial performance of 0.968 with the assumption of independent variables other constant. The results of data analysis showed that credit restructuring partially affected financial performance. The key is that credit restructuring has a significant positive effect on the financial performance of the Buleleng Regency LPD during the Covid-19 Pandemic.
\end{abstract}

\section{INTRODUCTION}

Village Credit Institutions (LPD) are village financial institutions that carry out traditional village finance functions to manage village financial potential. This institution has great potential and has been proven to promote the welfare of rural communities by channeling credit and fulfilling the interests of the village itself (Astawa et al., 2016; Suarta \& Sudiadnyani, 2014). The definition of credit is the provision of money or bills that can be equated with it, based on a loan agreement or agreement between a bank and another party that requires the borrower to pay off his debt after a certain period of time with interest (Anastasiou et al., 2021; Balke et al., 2021; Liu \& Zhang, 2021). One of the successes of LPD, which is a community-based credit institution in Pakraman/customary villages, can be explained by the factors of government policies that are conducive to supporting its existence through the issuance of legal instruments in the form of regional regulations (Sanjaya et al., 2019; Sujana \& Mustanda, 2015). Other factors, the provision of credit based on traditional nuanced characters, the use of integrated social (customary) sanctions in awig-awig and perarem have encouraged the creation of a high level of effectiveness and business independence of LPDs (Suartana et al., 2020).

The Covid-19 pandemic has had a major impact on the economy in almost all sectors (Handayani et al., 2020; Hincal \& Alsaadi, 2021; Lyócsa et al., 2020). The Central Statistics Agency (BPS) noted that Indonesia's economic growth in the first quarter of 2020 grew slower by only $2.97 \%$. Covid-19 has succeeded in hitting the Indonesian economy precisely on two sides at once, the demand and supply sides (Indayani \& Hartono, 2020; Muhyiddin, 2020). LPD is one of the microfinance institutions affected by covid 19. LPD which usually provides credit services to their customers in order to carry out its function as a channeling institution (agent) is to collect funds from the community and distribute them in the form of 
credit so that the funds collected are productive and generate profits for the community (Prena \& Kustina, 2017; Wilatini \& Wirakusuma, 2019). Due to the COVID-19 pandemic, people's activities to carry out financial transactions such as saving and paying credit have decreased. This causes people to carry out more transactions in the form of withdrawing funds to meet their daily needs. The decrease in public interest in saving causes a decrease in the source of funds received by the LPD from third parties and this will have an impact on the profits obtained by the LPD so that the LPD's financial performance will decrease.

During the Covid-19 pandemic some LPDs experienced difficulties in their operational activities, so for business continuity, of course, various efforts need to be made. The implementation of various programs in an effort to support policies related to credit is taken to maintain LPD growth, one of which is the relaxation of credit restructuring policies for people who have credit in LPDs. The LPD that implements this policy, for example, is the LPD of the Traditional Village of Patas, Gerokgak. According to Financial Services Authority Regulation regulating economic stimulus during the Covid-19 period, credit restructuring is a program as an effort to improve the credit activities of debtors who have difficulty fulfilling their obligations. This policy was welcomed and gave little hope to LPDs and LPD customers. LPDs maintain the continuity of their business as well as their customers. Therefore, the responses, ideas and experiences of credit lenders on the implementation of policies in maintaining their business continuity need to be studied in depth. This policy will be able to affect the decline in NPL so that the company's financial performance will be stable and good. Financial performance is the company's ability to manage and control the resources needed to generate profits over a certain period (Gupta, 2021; Wang et al., 2021). The company's financial profit is identical to the company's profit, profit is the final goal obtained by the company where profits reach the company level. The definition of profit itself is more of a difference between income over expenses in one period and is referred to as sum assured, which is the opposite (Alkaraan et al., 2022; Wasan et al., 2022; Yu et al., 2022). High lending to an LPD is vulnerable to liquidity risk, namely the risk that arises because the LPD is unable or fails to meet short-term obligations when needed, due to lack of liquidity in the LPD (Mahaendrayasa \& Putri, 2017; Suwintana et al., 2018). Credit distribution is a very basic LPD activity and loan interest is the main source of income.

Basically, credit lending activities have a very large risk, namely the risk of credit repayments and have a significant impact on the viability of microfinance institutions such as LPDs if extended credit is not on target (Andreana \& Wirajaya, 2018; Damayanthi, 2011). Not all customers who get credit can return it properly and on time according to the agreement. If many debtors do not carry out their obligations properly, of course it will have a serious impact on the credit sector which is aimed at Non-Performing Loan Ratios (NPLS) in LPDs. NPL is a condition where the customer is unable to pay part or all of his obligations to the bank as agreed in the credit agreement (Ari et al., 2021; Karadima \& Louri, 2020; Tölö \& Virén, 2021). Non-performing loans or non-performing loans are the risks inherent in any lending by banks. The risk is in the form of a condition where the credit cannot be returned on time (Bolognesi et al., 2020; Konstantakis et al., 2016). NPL reflects credit risk, the smaller the NPL, the smaller the risk borne by the bank. Details of non-performing loans (NPL) are loans with non-current, doubtful, and poor quality. A high NPL ratio will endanger the health of the LPD and can even lead to bankruptcy. Previous research showed that credit restructuring had a negative effect on the number of non-performing loans (NPL) (Mardi, 2018). Furthermore, other research found that restructuring had an effect on performance (D. H. Sari et al., 2021). Then other research showed that credit restructuring had an effect on financial performance, NPL (NonPerforming Loans), NIM (Net Interest Margin) of banking during the Covid-19 Pandemic (Rachmadi et al., 2021). Based on the description above, this study aims to examine the effect of Loan Restructuring Relaxation on Financial Performance in LPD Buleleng Regency during the Covid-19 Pandemic.

\section{METHODS}

This research was conducted on LPDs in Buleleng Regency. The time of this research was carried out during covid 19. The scope of this research is limited to the financial performance of LPD which is influenced by the relaxation of credit restructuring. This study used healthy LPDs as the study population, amounting to 81 LPDs. The sampling technique used in this study was simple random sampling technique. The number of samples that will be used is 46 LPD. Research data will be collected using documentation and questionnaire methods. Documentation method to collect qualitative data by analyzing documents made by a company. While the questionnaire collects data by distributing written questions to respondents to be answered. After the questionnaires are collected again, a check is carried out on the feasibility of the questionnaire and a Validity and Reliability test is carried out. Furthermore, the data will be tabulated according to the research variables. The data analysis technique used in this study is simple linear regression analysis with the help of the SPSS 21 application. 


\section{RESULTS AND DISCUSSIONS}

\section{Results}

Variables in this study will be measured by several indicators. Credit restructuring consists of 3 indicators and financial performance consists of 5 indicators. The first test carried out in this study was validity test and second test is reliability test. In this study, the method used in the validity test is the product moment correlation. By comparing the calculated Sig with Sig 0.05. Each statement item can be said to be valid if the calculated sig is smaller than Sig 0.05 . Based on the results of data analysis that all the calculated sigs are smaller than sig 0.05 which means that all statements in the questionnaire are valid. In this research technique used in the reliability test is Cronbach's Alpha. To determine whether an instrument is reliable or not, it can use the limit value of Alpha 0.60. If the value of Cronbach's Alpha $>0.60$ then the instrument is declared reliable. The Cronbach's Alpha value of 0.907 is greater than the standard of 0.60 . This indicates that the statement to be used is reliable.

The classical assumption test in this study consists of several tests, including: Normality test, Multicollinearity test, and Heteroscedasticity Test. Normality test aims to test whether the data used in the study is normally distributed or not. The test uses the One-Sample Kolmogrov-Smirnov Test method with the condition that the Asymp value. Sig. (2-tailed) is greater than 0.05 then the research data is said to be normally distributed. The Multicollinearity test VIF value and tolerance value of the independent variable, namely credit restructuring. The VIF value is not more than 10 and the tolerance value is more than 0.10 , which is $1.00<10$ and $1.00>0.10$. These results mean that it is free from multicollinearity problems. The heteroscedasticity test was tested by looking at the scatterplot image and the results showed that the scattering points above and below or around zero did not form a pattern. So it can be concluded that the regression model does not contain heteroscedasticity. Based on these tests, it can be concluded that the regression equation in this study has passed the classical assumption test.

The next test is Simple Linear Regression Analysis. This method is used to estimate the effect of the credit restructuring variable on the financial performance variable. Based on the results of data analysis, 9.656 which means that if all the independent variables are constant, then the value of financial performance is 9.656 . The regression coefficient for credit restructuring $(\mathrm{X})$ is positive at 0.968 which means that each increase in credit restructuring by one unit will cause an increase in financial performance (Y) of 0.968 with the assumption that other independent variables are constant. The feasibility test of the research model was carried out with the $\mathrm{F}$ test ( $\mathrm{F}$ test) to find out whether the regression model used was feasible or not. The significant $\mathrm{F}$ test results indicate that the independent variable affects the dependent variable and the model is feasible. The model is feasible and the independent variables simultaneously have an influence on financial performance. This is indicated by the F value of 90.189 with a significance of 0.00 which is below the value of 0.05 . Analysis of the Coefficient of Determination (R2) shows how much the dependent variable can be explained by the independent variable. The Adjusted R-squared value is 0.665 , this value means that variations in financial performance can be explained by variations in the independent variable credit restructuring around $66.5 \%$ and the remaining $33.5 \%$ is explained by other variables outside the model. The $t$-test is used to determine how far the influence of the explanatory or independent variables individually explains the variation of the dependent variable. The credit restructuring variable (X) has a tvalue of 9.497 and a significance value of 0.00 . The significance value of 0.00 is smaller than the 0.05 significance level, meaning that credit restructuring $(\mathrm{X})$ partially affects financial performance $(\mathrm{Y})$.

\section{Discussion}

Based on the results of hypothesis testing, this study shows that the relaxation of credit restructuring has a positive and significant effect on the financial performance of LPDs in Buleleng Regency during the covid 19 pandemic. Credit restructuring is an improvement effort made in the distribution of credit activities to debtors who have difficulty fulfilling their obligations (Bawa \& Basu, 2020; Power et al., 2014). The management of non-performing loans must be carried out systematically with the most efficient cost and optimal results (Balke et al., 2021; Rachmadi et al., 2021). One of the ways to save non-performing loans is through credit restructuring (Bawa \& Basu, 2020; Power et al., 2014). The settlement step through credit restructuring is the most critical requirement, namely the willingness, good faith, and cooperation of the debtor and can follow the conditions determined by the bank (Bawa \& Basu, 2020; Hernández et al., 2015). Modification of credit terms, among others, is as follows. First, the reduction in interest rates is a form of credit restructuring that aims to provide relief to debtors so that the reduction in the amount of interest that must be paid each payment date is smaller than the previously determined interest rate. Second, the extension of the credit period is a form of credit restructuring that aims to relieve debtors from repaying their debts. Third, to save non-performing loans, it can be done by easing the burden on the debtor by reducing arrears on credit interest or the overall loan interest arrears. Reduction of principal loan arrears is the maximum credit restructuring provided by banks because the reduction of principal arrears 
is a vast bank sacrifice. After all, the bank's assets in the form of principal debt are not returned and are losses borne by the bank (Dwiantara et al., 2015; L. M. Sari et al., 2020). By conducting credit restructuring, of course, it will have an impact on the amount of NPL which is then directly related to financial performance. This illustrates that the policies carried out by the LPD in Buleleng district during the COVID19 pandemic were able to alleviate the problems faced by customers and so that non-performing loans could be minimized and the financial performance of the LPD remained stable. This finding supports the research stated that credit restructuring has the effect of holding back/reducing the increase in the formation of allowance for earning assets write-off (PPAP) which can affect bank profitability/performance, NPL (Non-Performing Loans) and NIM (Net Interest Margin) during the Covid-19 Pandemic (Rachmadi et al., 2021). In addition, the results of this study are also in line with research that credit restructuring has a negative effect on the number of non-performing loans (NPL) (Mardi, 2018).

\section{CONCLUSION}

Based on the results of research and discussion, it can be concluded that the relaxation of credit restructuring has a positive and significant effect on financial performance in LPD Buleleng Regency. The implementation of policies carried out by LPDs in Buleleng Regency is able to overcome the problems of its customers so that non-performing loans can be minimized and lead to stable financial performance in each LPD.

\section{REFERENCES}

Alkaraan, F., Albitar, K., Hussainey, K., \& Venkatesh, V. (2022). Corporate transformation toward Industry 4.0 and financial performance: The influence of environmental, social, and governance (ESG). $\begin{array}{lllll}\text { Technological Forecasting Change, } & 175 .\end{array}$ https://doi.org/10.1016/j.techfore.2021.121423.

Anastasiou, D., Bragoudakis, Z., \& Giannoulakis, S. (2021). Perceived vs actual financial crisis and bank credit standards: Is there any indication of self-fulfilling prophecy? Research in International Business and Finance, 58. https://doi.org/10.1016/j.ribaf.2021.101486.

Andreana, M. O. C., \& Wirajaya, I. G. A. (2018). Pengaruh Transparancy, Accountability, Responsibility, Independency, dan Fairness Pada Kinerja Keuangan Lembaga Perkreditan Desa. E-Jurnal Akuntansi, 23(2). https://doi.org/10.24843/EJA.2018.v23.i02.p19.

Ari, A., Chen, S., \& Ratnovski, L. (2021). The dynamics of non-performing loans during banking crises: A new database with post-COVID-19 implications. Journal of Banking \& Finance, 133. https://doi.org/10.1016/j.jbankfin.2021.106140.

Astawa, I. P., Tjokorda, G. R. S., Triyuni, N. N., \& Abdi, I. N. (2016). Performance of Microfinance Institution in Harmony Cultural Perspective in Bali. Procedia - Social and Behavioral Sciences, 129. https://doi.org/10.1016/j.sbspro.2016.04.051.

Balke, N. S., Zeng, Z., \& Zhang, R. (2021). Identifying credit demand, financial intermediation, and supply of funds shocks: A structural VAR approach. The North American Journal of Economics and Finance, 56. https://doi.org/10.1016/j.najef.2021.101375.

Bawa, J. K., \& Basu, S. (2020). Restructuring assets reform, 2013: Impact of operational ability, liquidity, bank capital, profitability and capital on bank credit risk. IIMB Management Review, 32(3). https://doi.org/10.1016/j.iimb.2019.10.009.

Bolognesi, E., Compagno, C., Miani, S., \& Tasca, R. (2020). Non-performing loans and the cost of deleveraging: The Italian experience. Journal of Accounting and Public Policy, 39(6). https://doi.org/10.1016/j.jaccpubpol.2020.106786.

Damayanthi, E. (2011). Pengungkapan Tanggung Jawab Sosial Lembaga Perkreditan Desa (Lpd) Berdasarkan Filosofi Tri Hita Karana. Jurnal Ilmiah Akuntansi Dan Bisnis, 6(2).

Dwiantara, I. K. P., Darmawan, N. K. S., \& Atmadja, I. B. P. (2015). Penanggulangan Kredit Macet Melalui Proses Restrukturisasi Pada Bank Rakyat Indonesia Cabang Negara, Kabupaten Jembrana. Kertha Semaya, 3(3).

Gupta, R. Das. (2021). Financial performance shortfall, ESG controversies, and ESG performance: Evidence from firms around the world. Finance Research Letters. https://doi.org/10.1016/j.frl.2021.102487.

Handayani, D., Hadi, D. R., Isbaniah, F., Burhan, E., \& Agustin, H. (2020). Corona virus disease 2019. Jurnal Respirologi Indonesia, 40(2), 119-129. https://doi.org/10.36497/jri.v40i2.101.

Hernández, S. M., Gil, E. G., \& Renart, M. A. (2015). Spanish credit institutions: do efficiency and solvency support the first decisions on bank restructuring from a financial point of view 2008-2012? Contaduría y Administració, 60(2). https://doi.org/g/10.1016/S0186-1042(15)30005-X. 
Hincal, E., \& Alsaadi, S. H. (2021). Stability analysis of fractional order model on corona transmission dynamics. Chaos, Solitons \& Fractals, 143, 110628. https://doi.org/10.1016/j.chaos.2020.110628.

Indayani, S., \& Hartono, B. (2020). Analisis Pengangguran dan Pertumbuhan Ekonomi sebagai Akibat Pandemi Covid-19. Jurnal Ekonomi Dan Manajemen Universitas Bina Sarana Informatika, 18(2). https://doi.org/10.31294/jp.v18i2.8581.

Karadima, M., \& Louri, H. (2020). Non-performing loans in the euro area: Does bank market power matter? International Review of Financial Analysis, 72. https://doi.org/10.1016/j.irfa.2020.101593.

Konstantakis, K. N., Michaelides, P. G., \& Vouldis, A. T. (2016). Non performing loans (NPLs) in a crisis economy: Long-run equilibrium analysis with a real time VEC model for Greece (2001-2015). Physica A: Statistical Mechanics and Its Applications, 456. https: //doi.org/10.1016/j.physa.2015.12.163.

Liu, L., \& Zhang, H. (2021). Financial literacy, self-efficacy and risky credit behavior among college students: Evidence from online consumer credit. Journal of Behavioral and Experimental Finance, 32. https: //doi.org/10.1016/j.jbef.2021.100569.

Lyócsa, Š., Baumöhl, E., Výrost, T., \& Molnár, P. (2020). Fear of the coronavirus and the stock markets. Finance Research Letters, 36. https://doi.org/10.1016/j.frl.2020.101735.

Mahaendrayasa, P. K. A., \& Putri, G. A. M. A. D. (2017). Pengaruh Prinsip-Prinsip Good Corporate Governance Terhadap Kinerja Keuangan Lembaga Perkreditan Desa (LPD) di Kota Denpasar. E-Jurnal Akuntansi, 21(2). https://doi.org/10.24843/EJA.2017.v21.i02.p04.

Mardi, R. W. (2018). Analisis Pengaruh Restrukturisasi Kredit Terhadap NPL di PT Bank Tabungan Negara (Persero) Tbk Cabang Medan. Jurnal Ilmiah Reasearch Sains, 4(2).

Muhyiddin. (2020). Covid-19, New Normal, dan Perencanaan Pembangunan di Indonesia. Jurnal Perencanaan Pembangunan: The Indonesian Journal of Development Planning, 4(2), 240-252. https://doi.org/10.36574/jpp.v4i2.118.

Power, C., O’Connor, R., McCarthy, O., Scopus, V. in, \& Ward, M. (2014). Merging into the mainstream? An empirically based discussion of the potential erosion of competitive advantage in a restructured Irish credit union movement. Journal of Co-Operative Organization and Management, 2(2). https://doi.org/10.1016/j.jcom.2014.09.001.

Prena, G. Das, \& Kustina, K. T. (2017). Kegiatan Sosial, Budaya, Dan Agama Dalam Menentukan Laba Lembaga Perkreditan Desa (Lpd) Kota Denpasar. E-Jurnal Akuntansi, 21(1).

Rachmadi, Febi, \& Suyono, E. (2021). The Credit Restructuring Phenomenon of The MSMEs And Its Effect On Banking Financial Performance During The Pandemic of Covid-19. Jurnal Ekonomi Dan Bisnis Volume, 5(1).

Sanjaya, N. M. W. S., Nopiyani, P. E., \& Rianita, N. M. (2019). Kualitas Laporan Keuangan Ditinjau dari Budaya Tri Hita Karana, GCG, Kompetensi SDM dan Manajemen Risiko Lembaga Perkreditan Desa. Jurnal Riset Akuntansi Dan Keuangan, 7(3). https://doi.org/10.17509/jrak.v7i3.17628.

Sari, D. H., Khairiyah, N. M., \& Ismawanto, T. (2021). Efektivitas Pelaksanaan Restrukturisasi Kredit Sebagai Strategi Penurunan Kredit Bermasalah Selama Pandemic Covid-19 Pegadaian Kanwil Balikpapan. Jurnal Studi Management Dan Bisnis, 8(2). https: //doi.org/10.21107/jsmb.v8i2.12589.

Sari, L. M., Musfiroh, L., \& Ambarwati, A. (2020). Restrukturisasi Kredit Bank Daerah X Pada Masa Pademi Covid-19. Jurnal Manajemen Dan Akutansi, 8(1).

Suarta, I. M., \& Sudiadnyani, I. O. (2014). Studi Faktor Penentu Penerimaan Dan Penggunaan Sistem Informasi Akuntansi Pada Lembaga Perkreditan Desa. Jurnal Sistem Informasi (Journal of Information System), 10(1). https://doi.org/10.21609/jsi.v10i1.377.

Suartana, I. W., Yasa, G. W., Setyari, N. P. W., \& Purnamawati, I. G. A. (2020). Resiliensi Bisnis Badan Usaha Milik Desa Pada Era Pandemi: Sebuah Pendekatan Studi Kasus. Jurnal Manajemen, Strategi Bisnis Dan Kewirausahaan, 14(2). https://doi.org/10.24843/matrik:jmbk.2020.v14.i02.p09.

Sujana, P. C., \& Mustanda, I. K. (2015). Pengaruh Cash Turnover, Loan to Deposit Ratio, Capit al Adequacy Ratio, dan Dana Pihak Ketiga terhadap Profitabilitas LPD. Jurnal Manajemen, Strategi Bisnis Dan Kewirausahaan, 8(2).

Suwintana, I. K., Sudhana, I. G. P. F. P., \& Hariyanti, N. K. D. (2018). Pengembangan Aplikasi Mobile Teller Lembaga Perkreditan Desa Berbasis Android. Matrix: Jurnal Manajemen Teknologi Dan Informatika, 83(10). https://doi.org/10.31940/matrix.v8i3.823.

Tölö, E., \& Virén, M. (2021). How much do non-performing loans hinder loan growth in Europe? European Economic Review, 136. https://doi.org/10.1016/j.euroecorev.2021.103773.

Wang, J., Li, J., \& Zhang, Q. (2021). Does carbon efficiency improve financial performance? Evidence from Chinese firms. Energy Economics, 104. https://doi.org/10.1016/j.eneco.2021.105658.

Wasan, P., Mulchandani, K., \& Mulchandani, K. (2022). Do changes in deferred revenue indicate future financial performance? Evidence from India. Journal of International Accounting, Auditing and 
Taxation, 46. https://doi.org/10.1016/j.intaccaudtax.2021.100441.

Wilatini, K. A. D., \& Wirakusuma, M. G. (2019). Pengaruh Pengendalian Internal Pada Efisiensi Kredit Di Lembaga Perkreditan Desa (LPD) Se-Kecamatan Sukawati Kabupaten Gianyar. E-Jurnal Akuntansi, 28(2). https://doi.org/10.24843/EJA.2019.v28.i02.p04.

Yu, P., Hao, R., Cai, Z., Sun, Y., \& Zhang, X. (2022). Does emission trading system achieve the win-win of carbon emission reduction and financial performance improvement? - Evidence from Chinese Ashare listed firms in industrial sector. Journal of Cleaner Production, 333. https://doi.org/10.1016/j.jclepro.2021.130121. 